\title{
PREDIKTOR KEBERHASILAN STUDI PADA MAHASISWA DI FAKULTAS PSIKOLOGI UIN SUNAN GUNUNG DJATI BANDUNG
}

\author{
Fenti Hikmawati, Nani Nuranisah Djamal, Agus Abdul Rahman \& Elisa Kurniadewi \\ Fakultas Psikologi UIN Sunan Gunung Djati Bandung \\ J1. Raya Cipadung No. 105 Bandung 10614 Telp (022) 7800525 email: fenhikmah@yahoo.com
}

This study will specifically investigate the personal factors of students, whether they are biographic, or suspected psychological effect on the success of studies in the faculty of Psychology. Demographic factors such as intelligence level factors, whether the school background of high school, vocational school, or MA, and majors of time in SMU / SMK / MA. These factors are investigated for allegedly influence the success of the study. If proven, empirically, the results of this study expected to be a consideration in the selection of new students of psychology faculty UIN Sunan Gunung Djati Bandung. During this selection system seems not yet to consider these factors. In fact, psychological test results of students' 2007-2008 force distribution of the IQ level of students was very varied between 78 to 115 points. Not much different school backgrounds and majors. The design of this study applying correlational design, multiple regression. With multiple regression, it is possible to forecast a variable based on the values of some predictors. The assumption by using several predictors will make more accurate predictions. In addition, with multiple regression is statistically possible to measure the influence of several predictor variables to control the other predictor variables (Blaikie, 2003). Research data, including: (1) The primary data is data related to emotional intelligence and social support, and (2) secondary data id data relating to the level of intelligence. Secondary data were obtained from laboratory psycho-tests held by the faculty of Psychology UIN SGD Bandung and the data contained in the faculty of Psychology UIN SGD Bandung. Results of data analysis shows that the correlation coefficient of the three independent variables with dependent variables for 0409 with a value of $R 2$ of 0167. It shows that 16.7 percent of the variation of study success is determined by emotional intelligence, social support, and level of intelligence. Level intelligence backgrounds of students majoring in natural science majors were higher than social science or language. Meanwhile, 83.3 percent more determined by other variables.

Keyword: study, success

\section{Pendahuluan}

Pada tahun 2009 ini, program studi psikologi di UIN SGD Bandung genap berusia sebelas tahun. Suatu usia yang semestinya sudah lepas dari masa pembentukan (formation stage) dan mulai memasuki masa pertumbuhan (growth stage). Untuk memenuhi harapan tersebut, program studi psikologi sebaiknya mulai merencanakan dan menciptakan langkah-langkah menuju pertumbuhan. Langkah pertama yang penting dilakukan adalah evaluasi diri.
Evaluasi diri yang pernah dilakukan menunjukkan bahwa program studi psikologi ternyata masih dihadapkan pada banyak masalah yang antara lain berkenaan dengan keberhasilan studi mahasiswa. Data yang diperoleh menunjukkan bahwa mahasiswa psikologi relatif lama di dalam menyelesaikan studinya (10 sd 14 semester). Selain itu, ratarata IPK mahasiswa pun termasuk rendah (rata-rata 2,52). Indikator lain yang perlu dicari solusinya secepat mungkin adalah tingginya tingkat putus studi mahasiswa, baik karena 
drop out (DO), cuti, ataupun keluar tanpa pemberitahuan.

Masalah ini tentu bukanlah masalah sepele bagi sebuah program studi. Masalah ini merupakan masalah penting, serius, dan mendesak. Oleh karena itu, program studi psikologi harus segera mengambil langkahlangkah untuk memahami dan mengatasi masalah tersebut. Berdasarkan pada kepentingan tersebut, maka program studi kemudian merencanakan dan melakukan penelitian dengan tujuan mengidentifikasi faktor-faktor yang mempengaruhi keberhasilan dan ketidakberhasilan studi mahasiswa di Program Studi Psikologi UIN SGD Bandung.

Keberhasilan studi mahasiswa di suatu program studi merupakan bentukan dari banyak faktor. Ada banyak faktor yang berpengaruh baik pada tingkat personal, kelompok, maupun organisasional; Ada yang bersifat kognitif maupun non-kognitif. Pada tingkat personal, kompetensi dosen dan mahasiswa diduga akan memberikan pengaruh yang signifikan terhadap keberhasilan studi mahasiswa. Pada tingkat kelompok, interrelasi antar-mahasiswa dan antara mahasiswa dengan dosen tampaknya juga akan berpengaruh terhadap keberhasilan studi mahasiswa. Terakhir, pada tingkat organisasional, kurikulum, sarana dan prasarana, perpustakaan, laboratorium, serta kultur program studi juga diduga mempunyai pengaruh yang besar terhadap keberahasilan studi.
Penelitian ini akan secara khusus menginvestigasi faktor-faktor personal dari mahasiswa, baik yang bersifat biografis, ataupun psikologis yang diduga berpengaruh terhadap keberhasilan studi di fakultas Psikologi. Faktor-faktor demografik antara lain faktor tingkat kecerdasan, kecenderungan minat, latar sekolah apakah SMU, SMK, atau MA, dan jurusan waktu di SMU/SMK/MA. Faktor-faktor ini diteliti karena diduga berpengaruh ter-hadap keberhasilan studi. Jika terbukti secara empiris, maka hasil penelitian ini diharapkan akan menjadi pertimbangan di dalam seleksi masuk mahasiswa baru. Sebab, sistem seleksi selama ini tampaknya belum mempertimbangkan faktor-faktor tersebut. Faktanya, hasil psikotes terhadap mahasiswa angkatan 2007-2008 menunjukkan sebaran tingkat IQ mahasiswa yang sangat beragam. Yaitu berkisar antara 78 sampai 115-an. Tidak jauh berbeda dengan latar belakang sekolah, jurusan, kecenderungan minat.

Adapun, faktor-faktor psikologis yang diteliti adalah kecerdasan emosi, dan dukungan sosial. Kedua faktor tersebut diduga merupakan variabel antara yang mempengaruhi hubungan faktor-faktor biographis dan keberhasilan studi. Jika terbukti secara empiris, hasil penelitian ini akan merekomendasikan untuk dibentuknya lembaga bimbingan konseling untuk mahasiswa yang salah satu fungsinya adalah memberikan dukungan sosial pada mahasiswa dan mengembangkan kecerdasan emosional mahasiswa. 
Prediktor Keberhasilan Studi pada Mahasiswa di Fakultas Psikologi UIN Sunan Gunung Djati Bandung (Fenti Hikmawati, Nani Nuranisah Djamal, Agus Abdul Rahman \& Elisa Kurniadewi)

Telah banyak penelitian yang dilakukan terkait dengan keberhasilan seorang individu dalam studi, baik keberhasilan studi secara keseluruhan maupun keberhasilan dalam bidang pelajaran atau mata kuliah tertentu. Ada banyak faktor yang turut mempengaruhi keberhasilan seorang pelajar ataupun mahasiswa dalam menjalani studinya baik yang bersifat internal maupun eksternal. Biasanya setiap faktor itu tidak berdiri sendiri melainkan saling terkait satu sama lain.

Dalam penelitian ini, yang diperkirakan kuat sebagai predictor keberhasilan studi mahasiswa adalah faktor kecerdasan intelektual, kecerdasan emosional dan dukungan sosial. Penelitian tentang tema ini sebenarnya bukan hal yang baru. Ketiga variabel di atas seringkali menjadi tema umum yang dibahas dalam kajian mengenai keberhasilan seseorang dalam studi. Beberapa cuplikan hasil penelitian berikut adalah termasuk penelitian yang menjadi rujukan dan menginspirasi penelitian yang kami lakukan:

1. Penelitian yang dilakukan oleh Sawitri (2004) tentang hubungan kecerdasan emosional dengan prestasi belajar pada siswa SMU LAB SCHOOL di wilayah Jakarta Timur. Dari hasil penelitian diperoleh data analisis korelasi product moment menunjukkan korelasi (r) sebesar 0,248 dengan $p=0,002$. hal ini berarti bahwa terdapat korelasi antara kecerdasan emosional dengan prestasi belajar dengan arah hubungan positif. Artinya, jika kecerdasan emosional tinggi, maka prestasi belajar tinggi dan sebaliknya.
2. Maryani (2008) meneliti tentang pengaruh intelegensi dan model pembelajaran terhadap prestasi siswa pada mata pelajaran matematika di SMP Negeri Kota Surakarta pada Tahun 2008. Melalui penelitian tersebut, diperoleh hasil bahwa variabel intelegensi memberikan pengaruh signifikan terhadap tinggi rendahnya prestasi siswa dalam pelajaran matematika. Dimana siswa yang berintelegensi tinggi lebih baik dari pada siswa yang berintelegensi sedang dan rendah (F.1-.2 = 103,656, F.1-.3 = 197,244 dan $F=6,000$ ), serta siswa yang berintelegensi sedang prestasi belajarnya lebih baik daripada siswa yang berintelegensi rendah (F.2-.3 = 26,331 dan Fkritik= 6,000); (3) Hasil Anava dua jalan F $=5,55$ lebih besar Ftabel = 3,00 (H ditolak).

3. Penelitian lain yang lebih dekat dan memiliki daya dukung informasi yang tinggi untuk kepentingan penelitian ini adalah hasil penelitian yang dilakukan oleh dua orang mahasiswa Fakultas Psikologi UIN Sunan Gunung Djati Bandung. Penelitian pertama tentang stress beban studi kaitannya dengan self efficacy (Jaka 2009). Penelitian ini berangkat dari fenomena yang dikeluhkan oleh mahasiswa Fakultas Psikologi UIN Sunan Gunung Djati Bandung tentang beratnya menjalani proses pendidikan di Fakultas Psikologi. Respondennya adalah 41 orang mahasiswa Fakultas Psikologi UIN Sunan Gunung Djati Bandung angkatan 2007/2008. Dari hasil penelitian tersebut diperoleh indeks korelasi rank spearman sebesar -0,729. Hal 
ini menandakan tidak adanya hubungan yang signifikan antara self efficacy dengan stress beban studi. Atau dengan kata lain, tingginya keyakinan tentang kemampuan diri yang dimiliki oleh mahasiswa yang menjadi responden, tidak menjamin rendahnya stress beban studi yang mereka miliki. Dengan demikian, munculnya stress beban studi yang dialami mahasiswa ini bukan disebabkan karena rendahnya self efficacy. Kemungkinan penyebab lain, tidak diungkapkan secara jelas. Peneliti hanya menyarankan untuk dilakukan penelitian lanjutan dengan variabel yang berbeda.

4. Penelitian lain, dilakukan oleh Hani (2009) yang mengangkat tema tentang hubungan antara coping stress dengan prestasi mahasiswa pada mata kuliah psikodiagnostik I. Mata kuliah ini dianggap sebagai mata kuliah yang sulit dan berat terutama dalam proses pelaksanaannya, karena selain teori ada muatan praktikumnya juga. Dari hasil penelitian diperoleh data bahwa sebagian besar mahasiswa yang diteliti, memiliki coping stress yang berfokus pada masalah, bukan pada emosi. Artinya, pada umumnya, mahasiswa fakultas psikologi yang diteliti (angkatan 2004/2005) cukup efektif dan cukup mampu menangani stress yang mereka hadapi. Hipotesanya, jika coping stress berfokus pada masalah maka mestinya prestasi mahasiswa untuk mata kuliah psikodagnostik I juga baik. Tetapi pada faktanya tidak demikian, coping stress yang berfokus pada masalah tidak menjadi jaminan tingginya prestasi mahasiswa pada mata kuliah psikodiagnostik I. Untuk membahas persoalan ini, Hani (2009) memberikan beberapa kemungkinan alasan diantaranya mengutip pendapat Naylor (1972; dalam Gage, N. L. \& Berliner, D. C. 1979) bahwa salah satu faktor pribadi yang berpengaruh terhadap prestasi akademik adalah faktor kognitif: tingkat inteligensi, daya fantasi, kemampuan berbahasa, bakat khusus, organisasi kognitif. Naylor (1972) mengungkapkan bahwa prestasi belajar yang dicapai seorang mahasiswa erat kaitannya dengan tingkat inteligensi yang dimilikinya. Mahasiswa yang memiliki tingkat inteligensi tinggi akan lebih mudah untuk menangkap, mencerna, dan memahami materi pelajaran yang diterimanya dibandingkan dengan mereka yang tingkat inteligensinya rendah. Namun dalam penelitian Hani ini, intelegensi tidak termasuk variabel yang diteliti. Oleh karena itu, Saran dari penelitian ini: agar diupayakan penelitian lebih lanjut terhadap kemungkinan-kemungkinan melibatkan variabel lain yang turut berpengaruh pada pencapaian prestasi dan kelancaran studi mahasiswa Psikologi.

Terdapat beberapa kesamaan antara penelitian-penelitian di atas dengan penelitian yang kami lakukan, yaitu mempersoalkan factor-faktor yang mempengaruhi keberhasilan seseorang dalam mencapai prestasi akademik secara khusus dan keberhasilan studi secara umum. Faktor tersebut adalah factor internal 
Prediktor Keberhasilan Studi pada Mahasiswa di Fakultas Psikologi UIN Sunan Gunung Djati Bandung (Fenti Hikmawati, Nani Nuranisah Djamal, Agus Abdul Rahman \& Elisa Kurniadewi)

dan eksternal. Dalam hal ini, faktor internal yang dipilih adalah kecerdasan intelektual dan kecerdasan emosional. Sedangkan faktor eksternalnya adalah dukungan sosial.

Dipilihnya variabel dukungan sosial sebagai faktor eksternal yang mempengaruhi keberhasilan studi didasarkan pada pertimbangan bahwa:

Keberhasilan studi merupakan hasil akhir dari sebuah proses yang dijalani mahasiswa dalam menjalani kegiatan studinya. Karena studi itu merupakan proses, konsekuensinya akan ada tahapan yang dilalui, ada tantangan yang perlu dihadapi, ada kewajiban yang harus dijalankan, sehingga diperlukan kesiapan fisik dan mental untuk menjalaninya. Tantanga-tantangan tersebut berpotensi menimbulkan stress. Oleh karena itu dukungan dari lingkungan sekitar tentu dibutuhkan. Baik dukungan emosional, fasilitas atau alat, dukungan informasi, dukungan kelompok, dukungan akan harga diri (Sheridan \& Radmacher, 1992; Sarafino, 1998; Taylor, 1999).

Keberhasilan studi mahasiswa di suatu perguruan tinggi, seringkali diyakini murni menjadi tanggung jawab dari mahasiswa sendiri. Apapun yang terjadi, apakah mahasiswa tersebut mendapatkan rata-rata nilai yang buruk, menyelesaikan studi dengan waktu yang relatif lama, atau bahkan drop-out (DO), seringkali penyebabnya dialamatkan kepada mahasiswa itu sendiri (blaming the victim). Pandangan seperti ini tampaknya keliru, apalagi dari perspektif perguruan tinggi tersebut.
Keberhasilan studi mahasiswa merupakan bentukan dari tiga faktor: faktor organisme, faktor psikologis, dan faktor lingkungan (Crow \& Crow, 1973). Faktor lingkungan disini, termasuk perguruan tinggi yang bersangkutan, baik hardawe maupun softwarenya Yang termasuk hardware antara lain seperti ruang kuliah, laboratorium, alat praktikum, media pembelajaran, ataupun perpustakaan, sedangkan yang termasuk software antara lain kurikulum, kultur perguruan tinggi, aturan dan kebijakan, kompetensi dosen, sistem seleksi, sistem support, dan lain-lain. Jika mempertimbangkan besarnya kewenangan yang dimiliki, faktor perguruan tinggi sebenarnya merupakan faktor yang paling besar di dalam memberikan pengaruh terhadap keberhasilan studi mahasiswa. Perguruan tinggi mempunyai kewenangan yang luar biasa besar di dalam menentukan dan mengelola standard kualitas input, proses, dan output.

Perguruan tinggi mempunyai kewenangan di dalam menentukan baik standard input mahasiswa ataupun bagaimana sistem seleksinya. UIN Sunan Gunung Djati Bandung, terakhir menerapkan tiga jalur sistem penerimaan mahasiswa baru. Bisa melalui jalur SMPTN, PPA, atau ujian lokal. Dengan sistem ini, input mahasiswa menjadi sangat beragam. Menjadi sangat beragam lagi manakala sebelumnya tidak ditentukan standard input berdasarkan kebutuhan fakultas. Akibatnya, diduga akan muncul gap antara standard input yang ditetapkan oleh fakultas dengan kualitas input yang ada. Dan, gap ini kemudian diduga 
akan berpengaruh pada keberhasilan studi mahasiswa.

Fakultas psikologi UIN SGD Bandung tampaknya belum merumuskan standard input mahasiswa yang nantinya akan menjadi kriteria di dalam penerimaan mahasiswa baru. Keterbatasan data yang dimiliki mungkin menjadi alasan utama mengapa standard input itu belum ditentukan. Dalam konteks inilah, penelitian ini dilakukan. Penelitian ini bermaksud mengidentifikasi faktor-faktor personal calon mahasiswa yang berpengaruh terhadap keberhasilan studi dan relatif mudah untuk diukur.

Faktor personal yang secara umum diduga berpengaruh pada keberhasilan studi adalah faktor kecerdasan dan kecenderungan minat (Miron, 2004). Pengaruh kedua variabel tersebut terhadap keberhasilan studi, secara empirik, banyak dibuktikan. Walaupun, terakhir berkembang pemikiran yang disampaikan oleh Stenberg (dalam Aronson, 2002) bahwa tidak semua aspek dari kecerdasan bisa menjadi prediktor kuat terhadap keberhasilan. Menurutnya, ketiga aspek tersebut adalah kemampuan berfikir kritis, analitis, dan praktis.

Faktor lain yang diduga berpengaruh terhadap keberhasilan studi mahasiswa psikologi adalah faktor-faktor biographis dari mahasiswa yang dalam hal ini adalah latar belakang dan jurusan di sekolah. Hal ini perlu mendapatkan perhatian karena latar belakang dan jurusan di sekolah akan membantu (positive transfer learning) ataupun meng- hambat (negative transfer learning) proses belajar di psikologi.

Selain kecerdasan intelektual, latar belakang dan jurusan di sekolah, faktor dukungan sosial dan kecerdasan emosional tampaknya diduga akan sangat membantu mahasiswa menyelesaikan studinya dengan baik. Dengan lima belas karakteristik seperti yang disampaikan oleh Stein (2000) tampaknya kecerdasan emosi akan mempunyai efek yang cukup signifikan terhadap keberhasilan belajar. Menurut Stein, kecerdasan emosi ditandai oleh kesadaran-diri emosional, sikap asertif, kemandirian, penghargaan diri, aktualisasi diri, empati, tanggung jawab, hubungan antar pribadi, pemecahan masalah, uji realitas, sikap fleksibel, ketahanan menghadapi stres, pengendalian inpuls, kebahagiaan, dan optimisme.

Dari paparan di atas, prediktor keberhasilan studi mahasiswa Fakultas Psikologi UIN Sunan Gunung Djati Bandung dimungkinkan berfokus pada tiga hal yaitu: kecerdasan intelektual, kecerdasan emosional dan dukungan sosial. Sedangkan faktor biografik yang meliputi latar belakang sekolah dan latar belakang jurusan dipandang sebagai prediktor pendukung. Secara sederhana, kerangka berpikir dari penelitian ini adalah sebagai berikut: 
Prediktor Keberhasilan Studi pada Mahasiswa di Fakultas Psikologi UIN Sunan Gunung Djati Bandung

(Fenti Hikmawati, Nani Nuranisah Djamal, Agus Abdul Rahman \& Elisa Kurniadewi)

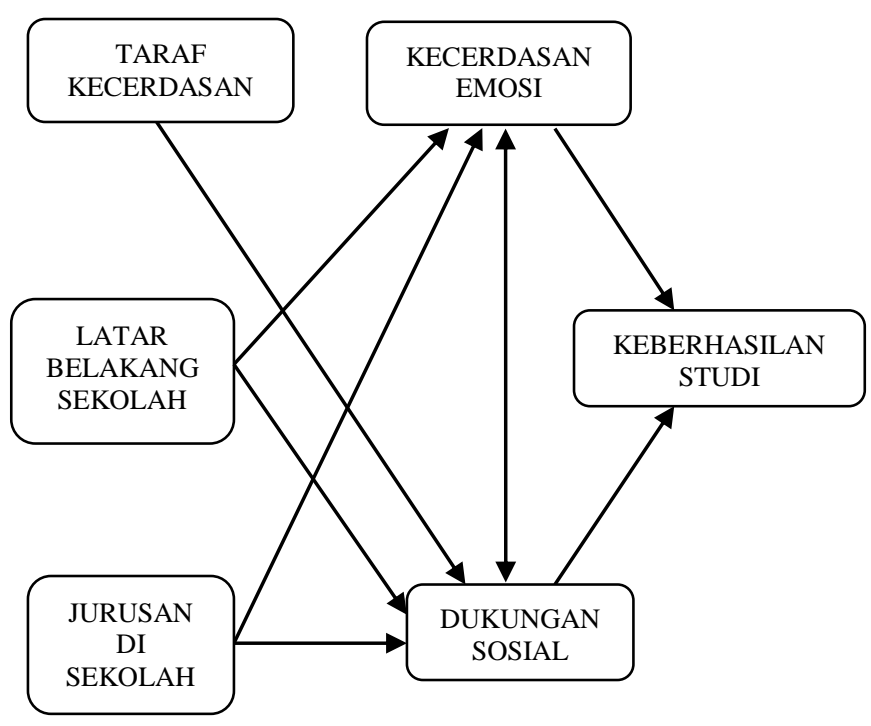

\section{Metode Penelitian}

Rancangan penelitian ini termasuk penelitian korelasional, multiple regression. Yaitu cara lain untuk menggambarkan dan mengevaluasi hubungan antara beberapa variabel dengan asumsi bahwa satu variabel berperan sebagai criterion variable, dan beberapa variabel berperan sebagai predictor variable (Clark-Carter, 2004). Adapun variabel yang akan dikorelasikan adalah:

1. Taraf kecerdasan, adalah total skor kecerdasan pada tes IQ dengan menggunakan IST (Intelligenz Struktur Test), yang terdiri dari SE, WA, AN, GE, ME, RA, ZR, FA, WU ;

2. Kecerdasan emosi : skor yang diperoleh responden pada skala kecerdasan emosional yang mengukur lima aspek kecerdasan emosional. Lima aspek kecerdasan tersebut adalah mengenali emosi diri sendiri, mengelola emosi, memotivasi diri sendiri, mengenali emosi orang lain, membina hubungan interpersonal.

3. Dukungan sosial : skor yang diperoleh responden pada skala dukungan sosial.
Skala dukungan sosial terdiri dari tiga aspek, yaitu kepedulian secara emosional, pemberian bantuan, dan pemberian informasi tentang situasi stres.

4. Prestasi belajar : hasil dari proses belajar yang ditunjukkan oleh indek prestasi kumulatif (IPK) dengan skala 4.

Hipotesis yang diajukan untuk mengetahui ada atau tidaknya pengaruh dari variabel yang bersangkutan secara umum dinyatakan sebagai berikut :

$\mathrm{H}_{0} \quad: \beta=0 \rightarrow$ Tidak terdapat pengaruh dukungan sosial, kecerdasan emosi, dan taraf kecerdasan terhadap prestasi belajar

$\mathrm{H}_{1} \quad: \beta \neq 0 \rightarrow$ Terdapat pengaruh dukungan sosial, kecerdasan emosi, dan taraf kecerdasan terhadap prestasi belajar

Pengujian hipotesis tersebut menggunakan analisis regresi. Analisis regresi dilakukan dengan menggunakan program SPSS versi 12 .

Populasi penelitian adalah mahasiswa program studi psikologi angkatan 2006/2007 dan angkatan 2007/2008. Dari seluruh maha-siswa yang ada terdapat 97 mahasiswa yang mengisi kuesioner penelitian, dan dari jumlah tersebut terdapat 9 orang yang dinyatakan gugur karena memiliki kelengkapan data yang tidak memadai. Oleh karena itu, subjek pene-litian secara keseluruhan menjadi 88 orang. Karena jumlahnya yang relatif sedikit dan dimungkinkan semua anggota populasi dijadikan sebagai subjek penelitian, maka penelitian ini berbentuk penelitian populasi. 


\section{Hasil}

\section{Deskripsi Subjek Penelitian}

a. Jenis kelamin :

1) Laki-laki berjumlah 22 orang (25\%)

2) Perempuan berjumlah 66 orang $(75 \%)$

b. Tempat tinggal :

1) Di rumah orang tua berjumlah 43 orang $(49 \%)$

2) Kos atau Kontrak berjumlah 31 orang $(35 \%)$

3) Lain-lain berjumlah 14 orang (16\%)

c. Asal sekolah :

1) Madrasah Aliyah (MA) berjumlah 31 orang $(35 \%)$

2) Sekolah Menengah Umum (SMU) berjumlah 54 orang $(61.5 \%)$

3) Lain-lain berjumlah 3 orang (3.5\%)

d. Jurusan di sekolah :

1) IPA berjumlah 49 orang (55.7\%)

2) IPS berjumlah 34 orang (38.6\%)

3) Lain-lain berjulah 5 orang (5.7\%)

e. Jalur masuk :

1) PPA berjumlah 18 orang $(20.5 \%)$

2) Ujian Lokal berjumlah 52 orang (59\%)

3) SPMB / SMPTN berjumlah 18 orang $(20.5 \%)$

f. Penghasilan orang tua :

1) 500 ribu s.d. 1 juta berjumlah 29 orang $(32.9 \%)$

2) 1 juta s.d. 2,5 juta berjumlah 32 orang $(36.4 \%)$

3) 2,5 juta s.d. 5 juta berjumlah 21 orang $(23.9 \%)$

4) 5 juta lebih berjumlah 6 orang $(6.8 \%)$ g. Tingkat Dukungan Sosial dan Kecerdasan Emosi

Dengan membandingkan antara mean hipotetik dengan mean empirik diperoleh kesimpulan bahwa mean hipotetik dukungan sosial (135) menunjukan besaran yang lebih kecil dibanding dengan mean empirik (188.3). Hal ini berarti subjek penelitian secara umum mempunyai dukungan sosial di atas rata-rata. Sama halnya dengan tingkat dukungan sosial, dengan membandingkan antara mean hipotetik dan mean empirik diperoleh kesimpulan bahwa tingkat kecerdasan emosi subjek termasuk di atas rata-rata $(158<201.6)$.

Kategori subjek penelitian dalam hal dukungan sosial berdasarkan norma:

$$
\begin{array}{ll}
45 \leq \mathrm{x} \leq 81 & =\text { Sangat rendah } \\
81<\mathrm{x} \leq 117 & =\text { Rendah } \\
117<\mathrm{x} \leq 153 & =\text { Rata-rata } \\
153<\mathrm{x} \leq 189 & =\text { Tinggi } \\
189<\mathrm{x} \leq 225 & =\text { Sangat tinggi }
\end{array}
$$

diperoleh hasil sebagai berikut :

1) Dukungan sosial sangat rendah sebanyak 0 orang

2) Dukungan sosial rendah sebanyak 0 orang

3) Dukungan sosial rata-rata sebanyak 13 orang

4) Dukungan sosial tinggi sebanyak 47 orang

5) Dukungan sosial sangat tinggi sebanyak 28 orang

Kategori Sujek penelitian dalam hal kecerdasan emosi berdasarkan norma berikut : 
Prediktor Keberhasilan Studi pada Mahasiswa di Fakultas Psikologi UIN Sunan Gunung Djati Bandung (Fenti Hikmawati, Nani Nuranisah Djamal, Agus Abdul Rahman \& Elisa Kurniadewi)

$$
\begin{array}{ll}
56 \leq \mathrm{x} \leq 96.8 & =\text { Sangat rendah } \\
96.8<\mathrm{x} \leq 137.6 & =\text { Rendah } \\
137.6<\mathrm{x} \leq 178.4 & =\text { Rata-rata } \\
178.4<\mathrm{x} \leq 219.2 & =\text { Tinggi } \\
219.2<\mathrm{x} \leq 224 & =\text { Sangat tinggi }
\end{array}
$$

diperoleh hasil sebagai berikut :

1) Kecerdasan emosi sangat rendah sebanyak 0 orang

2) Kecerdasan emosi rendah sebanyak 0 orang

3) Kecerdasan emosi rata-rata sebanyak 10 orang

4) Kecerdasan emosi tinggi sebanyak 65 orang

5) Kecerdasan emosi sangat tinggi sebanyak 13 orang

h. Taraf Kecerdasan

1) Taraf kecerdasan di bawah rata-rata (<90) sebanyak 18 orang

2) Taraf kecerdasan rata-rata (90 s.d. 110) sebanyak 56 orang

3) Taraf kecerdasan di atas rata-rata $(>110)$ sebanyak 14 orang

i. Tingkat Prestasi Belajar (IPK)

1) Prestasi belajar cumlaude (3.5 s.d. 4.00) terdapat 8 orang

2) Prestasi belajar amat baik (3.00 s.d. 3.49) terdapat 38 orang

3) Prestasi belajar baik (2.50 s.d. 2.99) terdapat 36 orang

4) Prestasi belajar cukup (2.00 s.d. 4.49) terdapat 4 orang

5) Prestasi belajar sangat tinggi tidak lulus (0.00 s.d. 1.99) terdapat 1 orang

\section{Pembahasan}

Perbedaan Prestasi Belajar Berdasarkan Jenis Kelamin, Tempat Tinggal, Jenis Sekolah, Jurusan di Sekolah, Penghasilan Orang Tua, dan Jalur Masuk

Dengan menggunakan analisis varians (ANAVA), diperoleh hasil sebagai berikut :

a. Nilai $F$ perbedaan prestasi belajar berdasarkan jenis kelamin adalah 1.614 dengan nilai $\mathrm{P}$ sebesar 0.207. Karena nilai P-nya lebih besar daripada $\alpha 0.05$, maka bisa disimpulkan bahwa tidak ada perbedaan prestasi belajar antara laki-laki dan perempuan.

b. Nilai $F$ perbedaan prestasi belajar berdasarkan tempat tinggal adalah 1.020 dengan nilai $\mathrm{P}$ sebesar 0.36 . Karena nilai P-nya lebih besar daripada $\alpha 0.05$, maka bisa disimpulkan bahwa tidak ada perbedaan prestasi belajar antara yang subjek yang tinggal di rumah orang tua, kos, atau lainnya.

c. Nilai $\mathrm{F}$ perbedaan prestasi belajar berdasarkan jenis sekolah adalah 0.543 dengan nilai $\mathrm{P}$ sebesar 0.583 . Karena nilai P-nya lebih besar daripada $\alpha 0.05$, maka bisa disimpulkan bahwa tidak ada perbedaan prestasi belajar antara subjek yang berlatar belakang MA (madrasah aliyah), SMU (sekolah menengah umum), dan Lain-lain.

d. Nilai $F$ perbedaan prestasi belajar berdasarkan jurusan di sekolah adalah 3.284 dengan nilai $\mathrm{P}$ sebesar 0.042 . Karena nilai P-nya lebih kecil daripada $\alpha$ 0.05, maka bisa disimpulkan bahwa ada perbedaan prestasi belajar antara subjek yang berlatar 
belakang jurusan IPA, IPS, dan lainlainnya.

e. Nilai $F$ perbedaan prestasi belajar berdasarkan penghasilan orang tua adalah 1.388 dengan nilai $\mathrm{P}$ sebesar 0.252 . Karena nilai P-nya lebih besar daripada $\alpha 0.05$, maka bisa disimpulkan bahwa tidak ada perbedaan prestasi belajar antara subjek dengan penghasilan orang tua yang berbeda-beda.

f. Nilai $F$ perbedaan prestasi belajar berdasarkan jalur masuk adalah 1.789 dengan nilai $\mathrm{P}$ sebesar 1.73. Karena nilai P-nya lebih besar daripada $\alpha$ 0.05, maka bisa disimpulkan bahwa tidak ada perbedaan prestasi belajar antara subjek yang masuk fakultas Psikologi melalui jalur PPA, Ujian Lokal, ataupun SPMB.

\section{Pengaruh Taraf Kecerdasan, Dukungan} Sosial, dan Kecerdasan Emosi terhadap Prestasi Belajar

Hipotesis statistik dari penelitian ini adalah sebagai berikut :

$\mathrm{H}_{0} \quad: \beta=0 \rightarrow$ Tidak terdapat penga-ruh dukungan sosial, kecerdasan emosi, dan taraf kecerdasan terhadap prestasi belajar

$\mathrm{H}_{1} \quad: \quad \beta \neq 0 \rightarrow$ Terdapat pengaruh dukungan sosial, kecerdasan emosi, dan taraf kecerdasan terhadap prestasi belajar

Hipotesis tersebut diuji dengan menggunakan multiple regression dan diperoleh hasil $\mathrm{F}$ sebesar 5.620 dengan $\mathrm{P}$ value lebih kecil dari nilai alpha 0.01. Hal itu menunjukkan bahwa Hipotesis nul ditolak dan hipotesis alternatif diterima. Artinya bahwa taraf kecerdasan, dukungan sosial, dan kecerdasan emosi secara bersama-sama berpengaruh secara signifikan terhadap prestasi belajar.

Namun demikian, pengaruh ketiga variabel tersebut secara mandiri tidak semuanya signifikan. Koefisien regresi dari masing-masing variabel tersebut adalah dukungan sosial sebesar 0.082 (tidak signifikan karena $\mathrm{P}>\alpha=0.494>0.05$ ), taraf kecerdasan sebesar 0.357 (signifikan karena $P$ $<\alpha=0.01<0.01)$ dan kecerdasan emosi sebesar 0.119 (tidak signifikan karena $\mathrm{P}>\alpha=$ $0.552>0.05$ ). Artinya, dukungan sosial dan kecerdasan emosi tidak secara signifikan berpengaruh terhadap prestasi belajar, sedangkan taraf kecerdasan secara signifikan berpengaruh terhadap prestasi belajar.

Diperoleh juga hasil yang menunjukkan bahwa koefisien korelasi ketiga variabel independen dengan variabel dependen sebesar 0.409 dengan nilai $\mathrm{R}^{2}$ sebesar 0.167 . Hal itu menunjukkan bahwa variasi pada prestasi belajar 16.7 persennya ditentukan oleh kecerdasan emosi, taraf kecerdasan, dan dukungan sosial. Sementara itu, 83.3 persennya lagi ditentukan oleh variabel lain.

\section{Simpulan dan Saran}

Simpulan

Tingkat dukungan sosial dan kecerdasan emosi,dengan membandingkan antara mean hipotetik dengan mean empirik diperoleh 
Prediktor Keberhasilan Studi pada Mahasiswa di Fakultas Psikologi UIN Sunan Gunung Djati Bandung (Fenti Hikmawati, Nani Nuranisah Djamal, Agus Abdul Rahman \& Elisa Kurniadewi)

kesimpulan bahwa mean hipotetik dukungan sosial (135) menunjukan besaran yang lebih kecil dibanding dengan mean empirik (188.3). Hal ini berarti subjek penelitian secara umum mempunyai dukungan sosial di atas rata-rata. Sama halnya dengan tingkat dukungan sosial, dengan membandingkan antara mean hipotetik dan mean empirik diperoleh kesimpulan bahwa tingkat kecerdasan emosi subjek termasuk di atas rata-rata $(158<201.6)$.

Dengan menggunakan analisis varians (ANAVA), perbedaan prestasi belajar berdasarkan jenis kelamin, tempat tinggal, jenis sekolah, jurusan di sekolah, penghasilan orang tua, dan jalur masuk diperoleh hasil sebagai berikut :

a. Nilai $\mathrm{F}$ perbedaan prestasi belajar berdasarkan jenis kelamin adalah 1.614 dengan nilai $\mathrm{P}$ sebesar 0.207. Karena nilai P-nya lebih besar daripada $\alpha 0.05$, maka dapat disimpulkan bahwa tidak ada perbedaan prestasi belajar antara laki-laki dan perempuan.

b. Nilai $\mathrm{F}$ perbedaan prestasi belajar berdasarkan tempat tinggal adalah 1.020 dengan nilai $\mathrm{P}$ sebesar 0.36 . Karena nilai P-nya lebih besar daripada $\alpha 0.05$, maka dapat disimpulkan bahwa tidak ada perbedaan prestasi belajar antara yang subjek yang tinggal di rumah orang tua, kos, atau lainnya.

c. Nilai $\mathrm{F}$ perbedaan prestasi belajar berdasarkan jenis sekolah adalah 0.543 dengan nilai $\mathrm{P}$ sebesar 0.583 . Karena nilai P-nya lebih besar daripada $\alpha 0.05$, maka bisa disimpulkan bahwa tidak ada per- bedaan prestasi belajar antara subjek yang berlatar belakang MA (madrasah aliyah), SMU (sekolah menengah umum), dan yang sederajat.

d. Nilai $\mathrm{F}$ perbedaan prestasi belajar berdasarkan jurusan di sekolah adalah 3.284 dengan nilai $\mathrm{P}$ sebesar 0.042 . Karena nilai P-nya lebih kecil daripada $\alpha 0.05$, maka dapat disimpulkan bahwa ada perbedaan prestasi belajar antara subjek yang berlatar belakang jurusan IPA, IPS, dan lainlainnya. Namun taraf kecerdasan ternyata berperan juga sebagai faktor moderator dari hubungan antara latar belakang jurusan dengan prestasi belajar. Artinya, kekuatan hubungan antara latar belakang jurusan dengan prestasi belajar itu dipengaruhi oleh faktor taraf kecerdasan. Atau apapun jurusannya, asal taraf kecerdasannya memadai, maka prestasi belajar mahasiswa tersebut diprediksikan akan tetap tinggi. Namun demikian, data yang kami dapatkan menunjukkan bahwa taraf kecerdasan mahasiswa yang berlatar belakang jurusan IPA ternyata lebih tinggi dibanding jurusan IPS ataupun bahasa

e. Nilai $\mathrm{F}$ perbedaan prestasi belajar berdasarkan penghasilan orang tua adalah 1.388 dengan nilai $\mathrm{P}$ sebesar 0.252 . Karena nilai P-nya lebih besar daripada $\alpha 0.05$, maka dapat disimpulkan bahwa tidak ada perbedaan prestasi belajar antara subjek dengan penghasilan orang tua yang berbeda-beda.

f. Nilai $F$ perbedaan prestasi belajar berdasarkan jalur masuk adalah 1.789 dengan 
nilai $\mathrm{P}$ sebesar 1.73. Karena nilai P-nya lebih besar daripada $\alpha 0.05$, maka dapat disimpulkan bahwa tidak ada perbedaan prestasi belajar antara subjek yang masuk fakultas Psikologi melalui jalur PPA, Ujian Lokal, ataupun SPMB.

Hipotesis statistik mengenai pengaruh taraf kecerdasan, dukungan sosial, dan kecerdasan emosi terhadap prestasi belajar diuji dengan menggunakan multiple regression dan diperoleh hasil $\mathrm{F}$ sebesar 5.620 dengan $\mathrm{P}$ value lebih kecil dari nilai alpha 0.01 . Hal itu menunjukkan bahwa Hipotesis nol ditolak dan hipotesis alternatif diterima. Artinya bahwa taraf kecerdasan, dukungan sosial, dan kecerdasan emosi secara bersama-sama berpengaruh secara signifikan terhadap prestasi belajar. Namun demikian, pengaruh ketiga variabel tersebut secara mandiri tidak semuanya signifikan. Koefisien regresi dari masing-masing variabel tersebut adalah dukungan sosial sebesar 0.082 (tidak signifikan karena $\mathrm{P}>\alpha=0.494>0.05)$, taraf kecerdasan sebesar 0.357 (signifikan karena $\mathrm{P}$ $<\alpha=0.01<0.01)$ dan kecerdasan emosi sebesar 0.119 (tidak signifikan karena $\mathrm{P}>\alpha=$ $0.552>0.05)$. Artinya, dukungan sosial dan kecerdasan emosi tidak secara signifikan berpengaruh terhadap prestasi belajar, sedangkan taraf kecerdasan secara signifikan berpengaruh terhadap prestasi belajar.

Diperoleh juga hasil yang menunjukkan bahwa koefisien korelasi ketiga variabel independen dengan variabel dependen sebesar 0.409 dengan nilai $\mathrm{R}^{2}$ sebesar 0.167 . Hal itu menunjukkan bahwa variasi pada prestasi belajar 16.7 persennya ditentukan oleh kecerdasan emosi, taraf kecerdasan, dan dukungan sosial. Sementara itu, 83.3 persennya lagi ditentukan oleh variabel lain.

\section{Saran}

Berdasarkan simpulan di atas maka diajukan saran-saran sebagai berikut:

1. Penerimaan mahasiswa fakultas psikologi UIN SGD Bandung sebaiknya memperhatikan latar belakang jurusan calon mahasiswa ketika di SMU, MA, atau yang lainnya. Calon mahasiswa fakultas Psikologi UIN SGD Bandung sebaiknya mempunyai latar belakang IPA atau calon mahasiswa yang berlatar belakang jurusan IPA sebaiknya lebih diprioritaskan daripada mahasiswa yang berlatar belakang jurusan IPS, bahasa, atau yang lainnya.

2. Hasil penelitian ini juga menunjukkan bahwa taraf kecerdasan merupakan prediktor yang signifikan berpengaruh terhadap tinggi-rendahnya prestasi belajar mahasiswa Fakultas Psikologi UIN SGD Bandung. Oleh karena itu, penerimaan mahasiswa khususnya Fakultas Psikologi UIN SGD Bandung selain melalui PPA, ujian local, atau SPMB/SMPTN juga sebaiknya dilakukan juga pengukuran kecerdasan (tes IQ), baik taraf maupun struktur kecerdasannya. 


\section{Daftar Pustaka}

Azwar, S. (1998). Tes Prestasi Fungsi dan Pengembangan Pengukutan Prestasi Belajar. Yogyakarta : Pustaka Pelajar Offset.

Cherness, C \& Goleman, D. (editor). 2001. The Emotionally Intelligent Workplace: How to Select, Measure, and Improve Emotional Intelligence in Individuals, Groups, and Organization. Jossey-Bass Wiley Company. Sun Francisco

Depag RI. (2004). Al-Qur'an dan Terjemahnya. Bandung: CV. Penerbit JARTLiteratur:

Departemen Republik Indonesia. (2006). Quran Tajwid dan Terjemahnya. Jakarta: Maghfirah Pustaka.

Goleman, D. (2000). Emotional Intelligence (terjemahan). Jakata : PT Gramedia Pustaka Utama.

Hani. (2009). Hubungan antara Coping Stress dengan Prestasi Mata Kuliah Psikodiagnostik I pada Mahasiswa Fakultas Psikologi Angkatan 2004-2005. Skripsi (tidak diterbitkan)

Laforge, R. (2001). An Overview of Social Support Theory.

Maryani. (2008). Pengaruh Intelegensi dan Model Pembelajaran terhadap Prestasi Siswa pada Mata Pelajaran Matematika di SMP Negeri Kota Surakarta.

Nasrul, HI. (2003). Hubungan Dukungan Sosial dengan Daya Tahan Stress pada Ibu Hamil Kelompok Resiko Tinggi di Desa Pamentasan dan Desa Gajah Mekar Kecamatan Soreang Kabupaten Bandung.Bandung:UIN Sunan Gunung Djati Bandung.

Neisser, U.; Boodoo, G.; Bouchard Jr, T.J.; Boykin, A.W.; Brody, N.; Ceci, S.J.; Halpern, D.F.; Loehlin, J.C.; Perloff, R.; Sternberg, R.J.; Others, (1998). "Intelligence: Knowns and Unknowns". Annual Progress in Child

Ratna, M. (2009). Semai Karakter Bangsa. http:/liht-org.tripod.com/pustaka/ kecerdasan pluskarakter.htm.

Winkel, WS (1997). Psikologi Pendidikan dan Evaluasi Belajar. Jakarta : Gramedia.

Witri. (2009). Hubungan antara Kecerdasan Emosional dengan Prestasi Belajar pada Siswa Kelas II SMU LabSchool.
Jakarta Timur: http:/one.indiskripsi.com/ node/ 1579 .

Yoesya, JP. 2009. Hubungan antara Self Efficacy dengan Stress Beban Studi pada Mahasiswa Fakultas Psikologi Angkatan 2007/2008. Skripsi (tidak diterbitkan) 
Psympathic, 2010, Vol. III, No.1: 15 - 28 